\title{
MEMBANGUN ALTRUISME PADA SISWA SMP BUSTANUL MAKMUR GENTENG BANYUWANGI
}

\author{
Imam Mashuri $^{1)}$, Imam Wahyono ${ }^{2)}$, Eka Ramiati $^{3)}$ \\ Institut Agama Islam (IAI) Ibrahimy Genteng Banyuwangi, Indonesia \\ e-mail: mashuri5758.aba@gmail.com
}

\begin{abstract}
Altruism is behavior and voluntary help that departs from a sincere heart, which is positive, and without and beneficial to others. Entering Era 4.0 makes some people behave selfishly, selfishly and don't care about others. This is a challenge for parents and teachers as educators, to build altruime attitudes in children from an early age, one of which is through the school environment.
\end{abstract}

KEYWORDS: Altruisme, Behavior, Voluntary

\begin{tabular}{|c|c|c|}
\hline Accepted: & Reviewed: & Published: \\
December 28 2020 & January 10 2021 & February 15 2021 \\
\hline
\end{tabular}

\section{PENDAHULUAN}

Altruisme adalah konsep yang biasanya dibedakan dari egoisme dan individualisme. Altruisme adalah sikap yang mementingkan kebutuhan dan kepentingan orang lain (Abercrombie et al., 2010, p. 23). Altruisme adalah paham (sifat) suka memperhatikan dan mengutamakan kepentingan orang lain, cinta yang tidak terbatas terhadap sesama manusia (kebalikan egoisme). Sikap manusia yang mungkin bersifat naluri berupa dorongan untuk berbuat jasa kepada orang lain (Departemen Pendidikan dan Kebudayaan, 1990, p. 24). Menurut Reber \& Reber (2010, p. 34), altruism (altruisme) yakni bersikap sedemikian rupa untuk meningkatkan rasa aman, terpuasnya kepentingan atau kebahagiaan hidup orang lain, meski di saat yang sama membahayakan keselamatan hidupnya sendiri.

Altruisme adalah tindakan sukarela untuk membantu orang lain tanpa pamrih, atau ingin sekadar beramal baik. Suatu perilaku dikatakan altruistik tergantung pada tujuan si penolong. Keterikatan antar individu diharapkan dapat menumbuhkan kesediaan untuk memberikan bantuan kepada orang lain kapanpun dan tanpa mengharapkan imbal balik. Sedangkan menurut Myers (2012, p. 187) menyebutkan bahwa altruisme adalah kebalikan dari egoisme. Orang yang altruistis, peduli dan mau membantu meskipun jika tidak ada 
keuntungan yang ditawarkan atau tidak ada harapan ia akan mendapatkan kembali sesuatu.

Altruisme merupakan bentuk khusus dalam penyesuaian perilaku yang ditujukan demi kepentingan orang lain, biasanya merugikan diri sendiri dan biasanya termotivasi terutama oleh hasrat untuk meningkatkan kesejahteraan orang lain agar lebih baik tanpa mengharapkan penghargaan. Altruisme mencakup beberapa aspek tindakan antara lain berbagi, membantu orang lain, baik hati, dan kerja sama. Sedangkan aspeknya menurut Pillavin \& Charng (1990, p. 30), yakni menguntungkan orang lain, dilakukan secara sukarela, dilakukan secara sengaja, tujuan yang dicapai harus bermanfaat, dilakukan tanpa mengharapkan imbalan apapun.

Desmita (Desmita, 2010, p. 243), mendefinisikan altruisme sebagai tahap di mana individu melakukan tindakan menolong secara sukarela. Tindakannya semata-mata hanya bertujuan menolong dan menguntungkan orang lain tanpa mengharapkan hadiah dari luar. Tindakan menolong dilakukan karena pilihannya sendiri dan didasarkan pada prinsip-prinsip moral. Sepanjang menyangkut keselamatan orang lain, individu dapat menilai kebutuhan orang lain, simpati kepada orang lain yang menderita dan membutuhkan bantuan, dan tidak mengharapkan keuntungan timbal balik untuk tindakannya.

Auguste Comte sebagai orang pertama yang menggunakan istilah altruisme yang berasal dari kata alter artinya orang lain, membedakan antara perilaku menolong yang altruis dengan perilaku menolong yang egois. Menurutnya dalam memberikan pertolongan, manusia memiliki motif (dorongan), yaitu altruis dan egois. Kedua dorongan tersebut sama-sama ditujukan untuk memberikan pertolongan. Perilaku menolong yang egois tujuannya justru memberi manfaat untuk diri si penolong atau dia mengambil manfaat dari orang yang ditolong. Sedangkan perilaku menolong altruis yaitu perilaku menolong yang ditujukan semata-mata untuk kebaikan orang yang ditolong (Desmita, 2008, pp. 131-132). Berdasarkan pendapat para tokoh di atas dapat disimpulkan bahwa altruisme merupakan perilaku dan tindakan menolong secara sukarela yang berangkat dari keikhlasan hati, yang bersifat positif, tanpa pamrih serta bermanfaat bagi orang lain.

Adapun seseorang melakukan tindakan altruistik tidak lepas dari latar belakang yang melandasinya. Ada beberapa teori yang menjelaskan latar belakang tersebut. 


\section{Teori Evolusi}

Dalam perspektif evolusi dinyatakan bahwa kecondongan untuk membantu adalah bagian dari warisan evolusi genetik. Gen dalam diri manusia telah mendorong manusia memaksimalkan kesempatan berlangsungnya suatu gen agar tetap lestari(Sarwono \& Eko, 2009, pp. 125-126). Hal yang menjadi sorotan dalam perspektif ini ketika seseorang menolong, yaitu.

a. Perlindungan kerabat (kin protection)

Menurut teori ini, kecenderungan seseorang untuk menolong orang lain yang tergolong kerabat atau seseorang yang masih memiliki ikatan darah. Kedekatan gen secara biologis membuat manusia terprogram secara alami untuk menolong orang yang masih tergolong kerabatnya.

b. Timbal balik biologis (biological reciprocity)

Motif seseorang menolong orang lain sebagai antisipasi agar mendapat pertolongan sebagai balasan dari orang yang telah ditolong dan bila ia tidak menolong, maka nantinya ia pun tidak akan mendapat pertolongan.

\section{Teori Belajar}

Perspektif belajar menekankan pentingnya proses belajar untuk membantu orang. Sesuai dengan pendapat Degeng dalam (Faishol, 2018), mengemukakan bahwa pembelajaran adalah upaya untuk membelajarkan pebelajar. Hal ini dimulai sejak dini, saat di mana anak diajari untuk saling berbagi dan menolong. Ketika seorang anak memberikan bantuan maka anak akan diberi reinforcement. Terdapat dua teori yang menjelaskan tingkah laku menolong, yakni teori belajar sosial (social learning theory) dan teori pertukaran social (social exchange theory).

Pada teori belajar sosial, alasan seseorang menolong adalah karena dibiasakan oleh masyarakatnya untuk menolong dan juga masyarakat tersebut menyediakan ganjaran yang positif atas perbuatan tersebut. Reinforcement dan modeling sangat berperan penting dalam membentuk perilaku prososial.

Pada teori pertukaran sosial, interaksi sosial bergantung pada untung dan rugi yang terjadi. Sesuai dengan namanya, teori ini memandang tingkah laku sosial sebagai hubungan pertukaran antara memberi dan menerima (take and give relationship). Teori ini pun mengatakan bahwa interaksi manusia mengikuti prinsip ekonomi yaitu memaksimalkan ganjaran (untung) dan meminimalkan biaya (rugi).

Tingkah laku menolong juga bisa semata-mata hanya untuk menutupi kepentingan pribadi seseorang. Misal, seseorang melakukan melakukan suatu 
kebaikan hanya untuk mendapatkan pujian. Dengan demikian, keuntungan dari tingkah laku menolong dapat bersifat menolong untuk mendapatkan imbalan dari lingkungan (external self-rewards) atau menolong untuk mendapatkan kepuasan batin (internal self-rewards) (Myers, 2012).

\section{Teori Empati}

Empati merupakan respon yang kompleks, meliputi komponen afektif dan kognitif. Seseorang dapat merasakan apa yang orang lain rasakan melalui komponen afektif dan seseorang memahami apa yang orang lain rasakan beserta alasannya. Daniel Batson (dalam Sarwono \& Eko, 2009, pp. 128-129), menjelaskan bahwa terdapat hubungan antara empati dengan tingkah laku menolong serta menjelaskan bahwa empati adalah sumber dari motivasi altruistik.

a. Hipotesis empati altruisme (empathy altruism hypothesis)

Munculnya perasaan empati yang mendorong untuk melakukan pertolongan ketika melihat penderitaan orang lain. Dalam hipotesis empati altruisme dikatakan bahwa perhatian yang empatik yang dirasakan seseorang terhadap penderitaan orang lain akan menghasilkan motivasi untuk mengurangi penderitaan orang tersebut. Motivasi menolong ini menjadi sangat kuat sehingga seseorang bersedia terlibat dalam aktivitas menolong yang tidak menyenangkan, berbahaya bahkan mengancam jiwanya. Dengan demikian, motivasi seseorang untuk menolong adalah karena orang lain yang membutuhkan bantuan dan rasanya menyenangkan bila dapat berbuat baik.

b. Orang selalu menginginkan adanya perasaan positif pada dirinya dan berusaha untuk mengurangi perasaan negatif. Melihat orang menderita dapat membuat perasaan seseorang menjadi tidak nyaman, sehingga ia berusaha untuk mengurangi perasaan tidak nyamannya dengan cara menolong orang tersebut.

c. Hipotesis kesenangan empatik (emphatic joy hypothesis)

Pada hipotesis ini dijelaskan bahwa seseorang akan menolong dengan memperkirakan akan dapat ikut merasakan kebahagiaan sebagaimana kebahagiaan orang yang ditolongnya, atau dengan kata lain seseorang yang menolong perlu mengetahui bahwa tindakannya akan memberikan pengaruh positif bagi orang yang akan ditolong. 


\section{Teori Perkembangan Kognisi Sosial}

Diperlukan sejumlah informasi yang harus diproses secara cepat sebelum seseorang memutuskan untuk memberikan dalam merespon suatu situasi darurat. Dapat dikatakan, tingkah laku menolong melibatkan proses kognitif seperti persepsi, penalaran, pemecahan masalah dan pengambilan keputusan. Pendekatan kognisi berfokus pada pemahaman yang mendasari suatu tingkah laku sosial (Sarwono, 2009, p. 328).

\section{Teori Norma Sosial}

Menurut teori ini terdapat dua bentuk norma sosial yang memotivasi seseorang untuk melakukan tingkah laku menolong, yaitu norma timbal- balik (the reciprocity norm) dan norma tanggung jawab sosial (the social responsibility norm). Norma timbal balik adalah salah satu norma yang bersifat universal, di mana seseorang harus menolong orang yang pernah menolongnya. Hal ini menyiratkan adanya balas budi dalam kehidupan bermasyarakat. Dengan demikian, seseorang harus menolong orang lain karena kelak di masa mendatang ia akan ditolong oleh orang lain atau ia pernah ditolong orang pada masa sebelumnya (Sarwono \& Meinarno, 1999, pp. 130-131).

Jika pada norma timbal-balik mengharuskan seseorang berbuat seimbang (antara memberi dan menerima) dalam sebuah hubungan sosial, maka dalam norma tanggung jawab sosial, orang harus memberikan pertolongan kepada orang yang membutuhkan, pertolongan dilakukan tanpa mengharapkan balasan di masa datang. Norma ini memotivasi orang untuk memberikan bantuan kepada orangorang yang lebih lemah dari dirinya, misalnya membantu orang yang cacat, atau membantu orang yang sudah tua.

Myers (Myers, 2012) membagi perilaku altruisme kedalam beberapa aspek yaitu pertama, memberikan perhatian terhadap orang lain di mana seseorang membantu orang lain karena adanya kasih sayang, pengabdian, kesetiaan yang diberikan, tanpa ada keinginan untuk memperoleh imbalan untuk dirinya sendiri. Kedua, membantu orang lain di mana seseorang membantu orang lain didasari oleh keinginan yang tulus dan dari hati nurani orang tersebut tanpa adanya pengaruh dari orang lain. Ketiga, yaitu meletakkan kepentingan orang lain di atas kepentingan pribadi di mana dalam memberikan bantuan kepada orang lain kepentingan yang bersifat pribadi dikesampingkan dan lebih fokus terhadap kepentingan orang lain.

Perilaku altruisme dipengaruhi oleh beberapa faktor yaitu faktor situasional dan faktor internal. Adapun faktor situasional dibagi menjadi enam, di 
antaranya lingkungan, daya tarik, atribusi terhadap korban, modeling, tekanan waktu, dan kebutuhan korban. Sedangkan faktor internal dibagi menjadi lima yaitu suasana hati, sifat, jenis kelamin, tempat tinggal dan pola asuh. Faktor yang mempengaruhi perilaku altruisme (Sarwono, 2009), sebagai berikut.

\section{a. Faktor situasional}

Faktor-faktor situasional yang dapat mempengaruhi perilaku altruisme yaitu sebagai berikut.

1) Lingkungan bystanders

Bystanders atau orang-orang yang berada di sekitar tempat kejadian mempunyai peran yang besar dalam mempengaruhi seseorang saat memutuskan untuk menolong ketika dihadapkan pada keadaan darurat, efek bystander terjadi karena adanya pengaruh sosial, yaitu pengaruh dari orang lain yang dijadikan acuan dalam menginterpretasi situasi dan mengambil keputusan untuk menolong. Kedua, hambatan penonton, yaitu merasa dirinya dinilai oleh orang lain dan resiko membuat malu diri sendiri karena tindakannya untuk menolong kurang tepat. Ketiga, penyebaran tanggung jawab di mana membuat tanggung jawab untuk menolong menjadi terbagi karena hadirnya orang lain.

2) Daya tarik

Sejauh mana seseorang memiliki daya tarik akan mempengaruhi kesediaan orang untuk memberikan bantuan. Seseorang akan cenderung menolong orang yang memiliki kesamaan dengan dirinya. Seorang pemalu pada umumnya akan melakukan altruisme pada anggota kelompoknya terlebih dahulu kemudian baru terhadap orang lain karena adanya kesamaan pada dirinya.

3) Atribusi terhadap korban

Wainer mengatakan bahwa seseorang akan termotivasi untuk memberikan bantuan kepada orang lain bila ia berasumsi bahwa ketidak beruntungan korban adalah di luar kendali korban. Jadi, seseorang akan lebih bersedia memberikan sumbangan kepada pengemis yang cacat dan tua dibandingkan dengan pengemis yang sehat dan masih muda.

4) Modeling

Ada model yang melakukan perilaku altruisme dapat memotivasi untuk seseorang memberikan pertolongan pada orang lain. 


\section{5) Tekanan waktu}

Orang yang sibuk dan tergesa-gesa cenderung tidak melakukan altruisme, sedangkan orang yang punya banyak waktu luang lebih besar kemungkinannya untuk memberikan pertolongan kepada yang memerlukan.

\section{b. Faktor internal}

Faktor-faktor internal yang dapat mempengaruhi perilaku altruisme adalah sebagai berikut (Sarwono, 2009).

1) Suasana hati (mood)

Emosi seseorang dapat mempengaruhi kecenderungan untuk menolong. Emosi positif akan meningkatkan perilaku altruisme, namun jika situasinya tidak jelas, maka orang yang bahagia cenderung mengasumsikan bahwa tidak ada keadaan darurat sehingga tidak menolong. Sedangkan pada emosi negatif, seseorang yang sedih kemungkinan menolongnya dapat membuat suasana hati lebih baik, maka dia akan memberikan pertolongan. Menurut Berkowitz dan William mengatakan bahwa orang yang suasana hatinya gembira akan lebih suka menolong, sedangkan seseorang yang berada dalam suasana hati sedih akan kurang suka melakukan altruisme, sebab menurut Berkowitz suasana hati dapat berpengaruh pada kesiapan seseorang untuk membantu orang lain.

2) Sifat

Berkaitan dengan sifat yang dimiliki seseorang, orang yang memiliki sifat pemaaf cenderung mudah menolong. Sedangkan orang yang memiliki self monitoring tinggi juga cenderung lebih penolong karena dengan menjadi penolong ia akan memperoleh penghargaan sosial yang lebih tinggi. Kebutuhan dan persetujuan juga mendukung perilaku altruisme. Karena individu yang membutuhkan pujian atau penghargaan jika situasi menolong memberikan peluang untuk mendapatkan penghargaan bagi dirinya maka ia akan meningkatkan perilaku altruismenya.

3) Jenis kelamin

Peranan gender terhadap kecenderungan seseorang untuk menolong sangat bergantung pada situasi dan bentuk pertolongan yang dibutuhkan. Laki-laki cenderung mau terlibat melakukan altruisme pada situasi darurat yang membahayakan. Sedangkan perempuan lebih mau terlibat dalam aktivitas altruisme pada situasi yang bersifat memberi dukungan emosi, merawat dan mengasuh. 
4) Tempat tinggal

Orang yang tinggal di pedesaan cenderung lebih penolong daripada orang yang tinggal di perkotaan terlalu banyak mendapat stimulasi dari lingkungan sehingga mereka harus selektif dalam menerima informasi yang banyak agar tetap bisa menjalankan perannya dengan baik, inilah yang menjadi penyebab orang-orang perkotaan altruismenya lebih rendah.

5) Pola asuh

Dalam perilaku altruisme tidak lepas dari peranan pola asuh di dalam keluarga. Pola asuh yang demokratis secara signifikan memfasilitasi adanya kecenderungan anak untuk tumbuh menjadi penolong, yaitu melalui peran orang tua dalam menentukan standar tingkah laku menolong. Menurut Mashoedi, pola asuh demokratis juga ikut mendukung terbentuknya internal locus of control di mana hal ini merupakan sifat asli kepribadian altruisme dari orang-orang desa karena mereka sibuk sehingga tidak peduli dengan kesulitan orang lain sebab mereka sudah overload dengan beban tugasnya sehari-hari.

6) Kebutuhan korban

Kesediaan untuk menolong dipengaruhi oleh kejelasan bahwa korban benar-benar membutuhkan pertolongan.

Menurut Latane dan Darley (dalam Faturochman, 2009, p. 74) ada empat tahapan yang dilalui seseorang sebelum sampai pada keputusan dan berbuat menolong orang lain.

a) Perhatian, orang tidak mungkin akan menolong bila dia tidak tahu adanya orang lain yang perlu ditolong. Untuk sampai pada perhatian terkadang sering terganggu oleh adanya hal-hal lain seperti kesibukan, ketergesaan, mendesaknya kepentingan lain dan sebagainya.

b) Interpretasi situasi, seseorang yang tergeletak di tepi jalan bisa diinterpretasikan sebagai gelandangan, pemabuk, korban kecelakaan atau yang lain. Apabila ternyata pemerhati ini menginterpretasikan gelandangan atau pemabuk maka tidak akan muncul suatu perbuatan. Sebaliknya, bila pemerhati menginterpretasikannya sebagai sesuatu yang membutuhkan pertolongan, misalnya dengan adanya darah, serangan atau permintaan tolong, maka kemungkinan besar akan diinterpretasikan sebagai korban yang perlu pertolongan.

c) Asumsi, setelah pemerhati menganggap bahwa orang tersebut memang betul butuh pertolongan maka munculah asumsi. Muncul tidaknya asumsi bahwa 
hal itu merupakan tanggung jawab pemerhati. Apabila tidak muncul asumsi ini, maka korban dibiarkan saja tanpa memberikan pertolongan.

d) Mengambil keputusan untuk menolong atau tidak. Meskipun sudah sampai tahap ketiga, pemerhati merasa bertanggung jawab memberi pertolongan pada korban, masih ada kemungkinan ia memutuskan tidak memberi pertolongan. Berbagai kekhawatiran bisa timbul yang menghambat terlaksananya pemberian pertolongan. Ini berbeda dengan bila ada keputusan bahwa ia memang harus menolong. Dengan adanya keputusan seperti itu, maka akan ada tindakan pertolongan. Dengan demikian untuk sampai pada perbuatan menolong, maka diperlukan keempat tahap secara berurutan.

SMP Bustanul Makmur Genteng berdiri sejak 2003, bertujuan mencetak manusia Indonesia yang unggul (berkualitas tinggi) seperti yang tercantum dalam tujuan Pendidikan Nasional tersebut di atas. Secara garis besar, SMP Unggulan Bustanul Makmur Genteng RSBI diarahkan untuk mencetak kader bangsa yang memiliki komitmen: keislaman, kebangsaan, dan kecendikiaan.

SMP Bustanul Makmur Genteng sangat memperhatikan kebutuhan siswa tidak saja dalam aktivitas pembelajaran, namun juga diasah nalar kritisnya serta disediakan kegiatan rekreatif dalam bentuk olah raga dan seni. Pembinaan kemampuan berorganisasi siswa menepati porsi yang cukup besar. Beberapa lembaga kesiswaan sebagai wadah berlatih berorganisasi yang bersifat internal sekolah tumbuh dan berkembang subur. Lembaga tersebut terdiri atas Student Council (SC) atau lebih dikenal dengan OSIS, Usaha Kesehatan Sekolah (UKS), Remaja Masjid Um Dua (Remas), Dewan Kerja Galang (DKG), Radio Utama FM, Palang Merah Remaja (PMR), dan kelompok belajar (English Club, Math Science Club).

Remaja Masjid Um Dua bekerjasama dengan Mahasiswa PPL II IAI Ibrahimy Genteng Banyuwangi menyelenggarakan kajian keislaman dalam rangka membangun sikap simpati, empati (altruisme) dikalangan siswa sSMP Bustanul Makmur. Kegiatan ini diikuti oleh seluruh siswa kelas VII dan VIII. Dan di pusatkan di Masjid sekolah. Narasumber berasal dari tenaga pendidik/dosen dari IAI Ibrahimy Genteng.

\section{METODE PELAKSANAAN}

Metode yang digunakan dalam pengabdian masyarakat adalah ceramah atau pidato, serta diskusi yakni dengan memadukan antara ilmu dan seni dalam 
menyampaikan ide atau pesan dihadapan seluruh siswa (kelas VII, VIII) SMP Bustanul Makmur Genteng

\section{HASIL DAN PEMBAHASAN}

Kegiatan pengabdian ini dilaksanakan bersamaan dengan kegiatan PPL II mahasiswa IAI Ibrahimy Genteng Banyuwangi selama satu bulan. Tugas dan kewajiban mahasiswa PPL II selain melaksanakan kegiatan pembelajaran di dalam kelas juga melaksanakan pendampingan terhadap kegiatan ekstrakurikuler. Narasumber kegiatan pengabdian kajian keislaman diambilkan dari Dosen Pendamping Lapangan atau dosen yang bertugas di IAI Ibrahimy Genteng. Subyek pengabdian, seluruh peserta didik SMP Bustanul Makmur, di bawah kordinator Guru pamong PPL II dan Remaja Masjid Um Dua (Remas). Narasumber memberikan materi penguatan tentang alturisme dengan mengenalkan perilaku altruisme di antaranya adalah digambarkan dalam AlQur'an. Kaum Anshar (penolong) adalah orang-orang Mekah yang baru berpindah ke Madinah. Orang-orang Mekah pindah ke Madinah sesuai dengan petunjuk pemimpin mereka, yaitu Nabi Muhammad saw. Orang-orang Anshar ini memberi pertolongan yang tulus terhadap saudara-saudara seagama mereka. Orang-orang anshar tidak menaruh keinginan dalam hati mereka terhadap apaapa yang diberikan kepada orang muhajirin.

Sikap altruisme merupakan bagian dari ajaran Islam bahkan Nabi Muhammad saw sebagai pembawa risalah ajaran Islam mendapat pengakuan langsung dari Allah swt sebagaimana telah diterangkan dalam Al Qur'an dalam surat Al Qolam ayat 4.

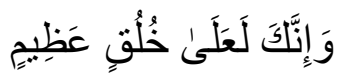

Dan sesungguhnya kamu benar-benar berbudi pekerti yang agung (Asy Syarifain, n.d., p. 960).

Sepatutnya, sebagai umat Nabi Muhammad saw meniru akhlaq Beliau, bahkan Allah menegaskan dalam surat An Nahl ayat 90 untuk berlaku adil dan berbuat kebajikan, dan melarang perbuatan keji, mungkar dan permusuhan.

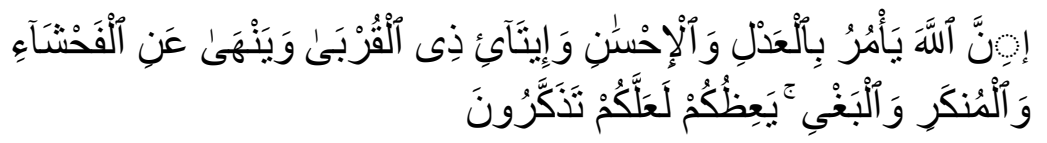


Sesungguhnya Allah menyuruh (kamu) berlaku adil dan berbuat kebajikan, memberi kepada kaum kerabat, dan Allah melarang dari perbuatan keji, kemungkaran dan permusuhan. Dia memberi pengajaran kepadamu agar kamu dapat mengambil pelajaran (Asy Syarifain, n.d.). kerusakan.

Dilanjutkan dengan surat Al Qashash Ayat 77 tentang larangan berbuat

$$
\begin{aligned}
& \text { وأبتغ فيماً ءاتكك أله ألدار آل أخرة و لا تنس نصييك من ألدنيا و أحسن كماً }
\end{aligned}
$$

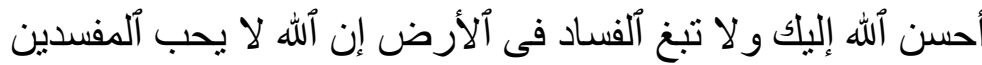

Dan layanan pada apa yang telah dianugerahkan Allah kepadamu (kebahagiaan) negeri akhirat, dan janganlah kamu melupakan bahagianmu dari (kenikmatan) duniawi dan persekutuan baiklah (kepada orang lain) yang Allah telah baik-baik, kepadamu, dan janganlah kamu kesalahan di (muka) bumi. Sesungguhnya Allah tidak suka orang-orang yang kerusakan (Asy Syarifain, n.d.).

Selanjutnya pemateri melanjutkannya dengan beberapa kutipan Al hadist terkait dengan akhlakul karimah dan kemuliaan orang-orang yang berakhlakul karimah.

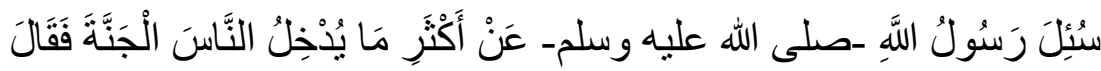

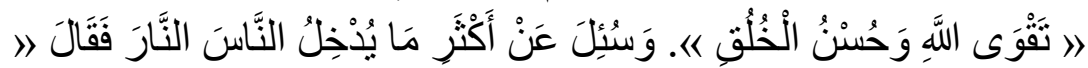

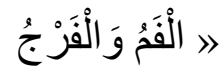

Artinya: "Rasulullah shallallahu 'alaihi wa sallam ditanya mengenai perkara yang banyak memasukkan seseorang ke dalam surga, beliau menjawab, "Takwa kepada Allah dan berakhlak yang baik." Beliau ditanya juga tentang perkara yang banyak memasukkan orang dalam neraka, beliau menjawab, "Perkara yang disebabkan karena mulut dan kemaluan." [HR. Tirmidzi no. 2004 dan Ibnu Majah no. 4246].

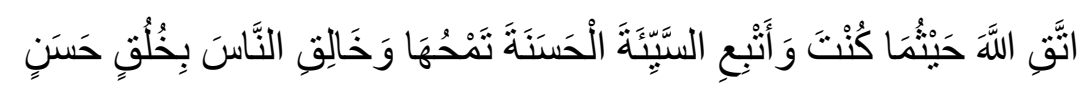
Artinya: "Bertakwalah kepada Allah di mana saja engkau berada. Ikutilah kejelekan dengan kebaikan niscaya ia akan menghapuskan kejelekan tersebut dan berakhlaklah dengan 
123 | Membangun Altruisme Pada Siswa SMP

Bustanul Makmur Genteng Banyuwangi

manusia dengan akhlak yang baik." [HR. Tirmidzi no. 1987 dan Ahmad 5/153].

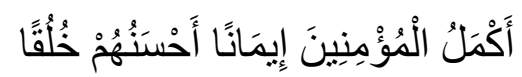

Artinya: "Orang mukmin yang paling sempurna imannya adalah yang paling baik akhlaknya." [HR. Abu Daud no. 4682 dan Ibnu Majah no. 1162.]

Penguatan dengan dalil-dalil nash dan disertai dengan contoh perilaku akhlakul karimah orang-orang sholeh masa lalu, menjadikan suasana diskusi menjadi menarik dan diminati oleh peserta. Munculnya sesi tanya jawab dan banyaknya peserta yang bertanya serta berani menyampaikan pendapatnya sehingga suasana diskusi aktif.

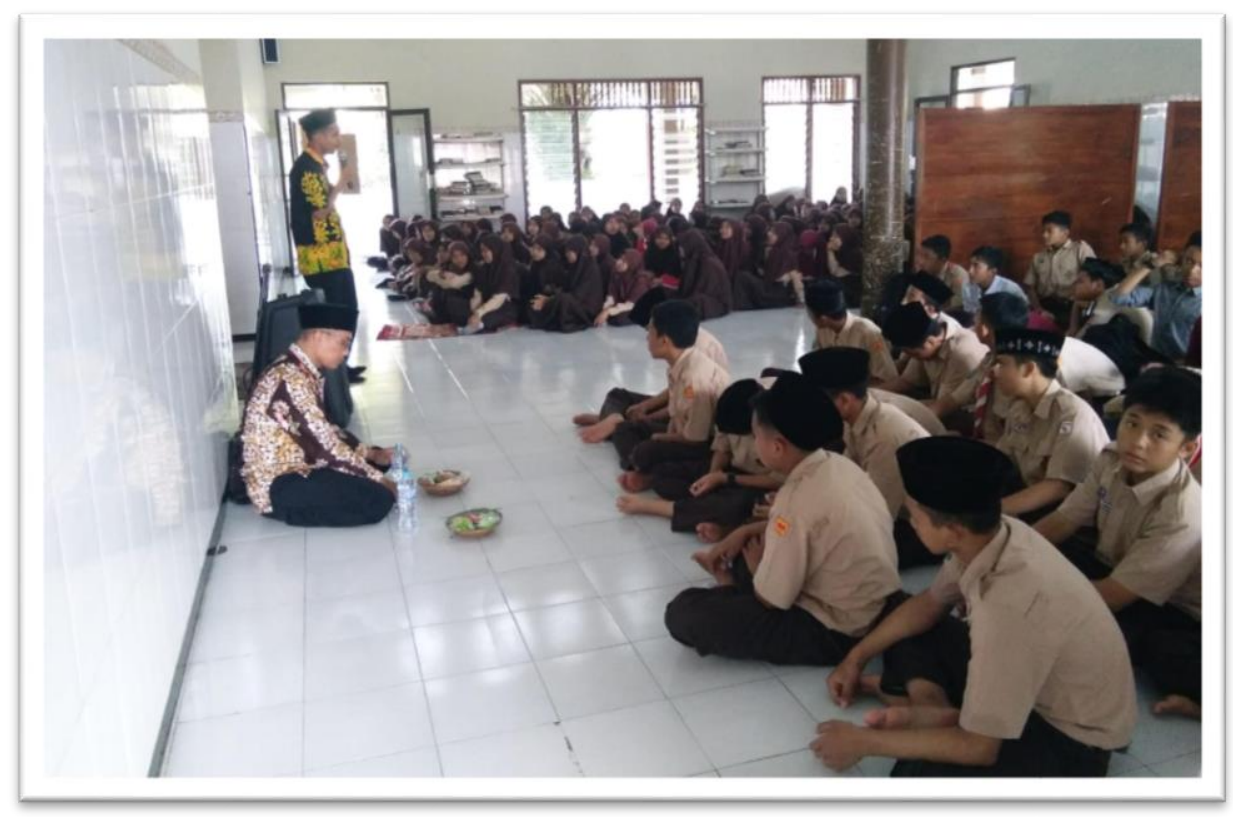

Gambar 1. Pembukaan Acara 
Imam Mashuri, Imam Wahyono \& Eka Ramiati | 124

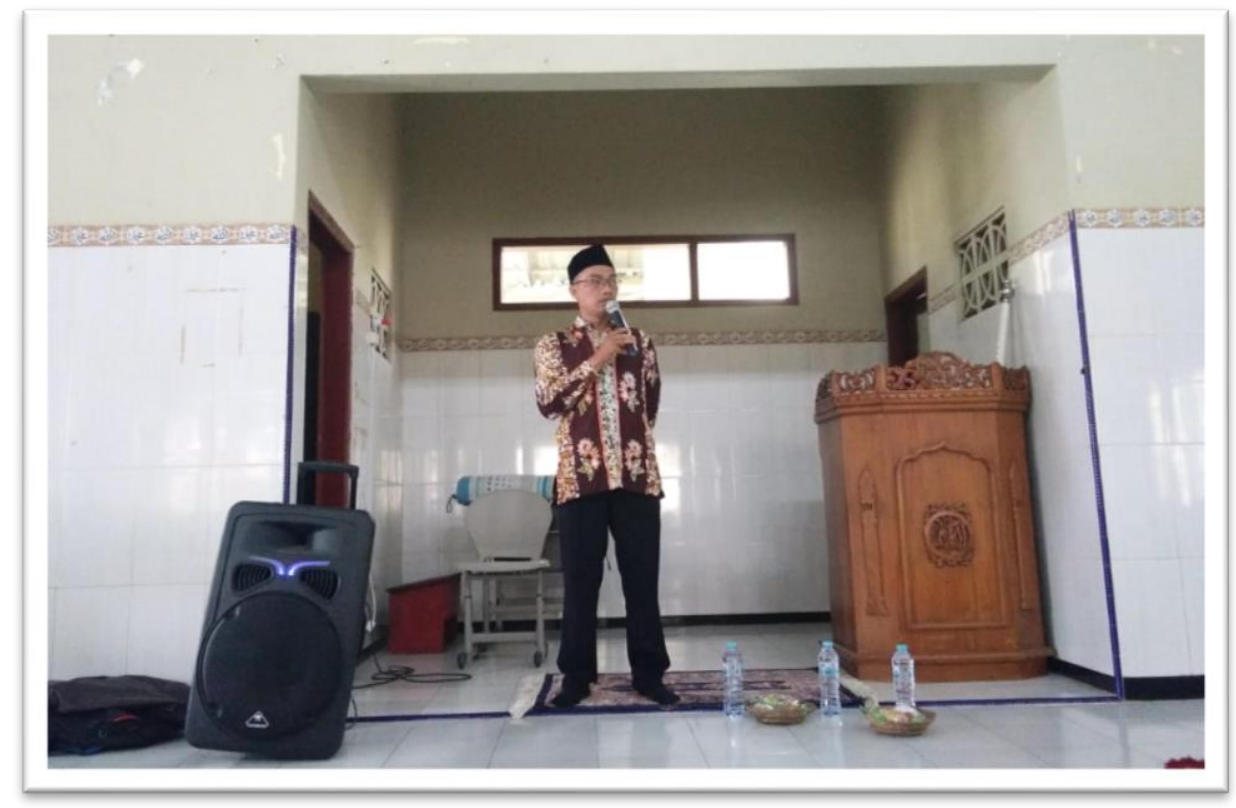

Gambar 2. Penyampaian Materi

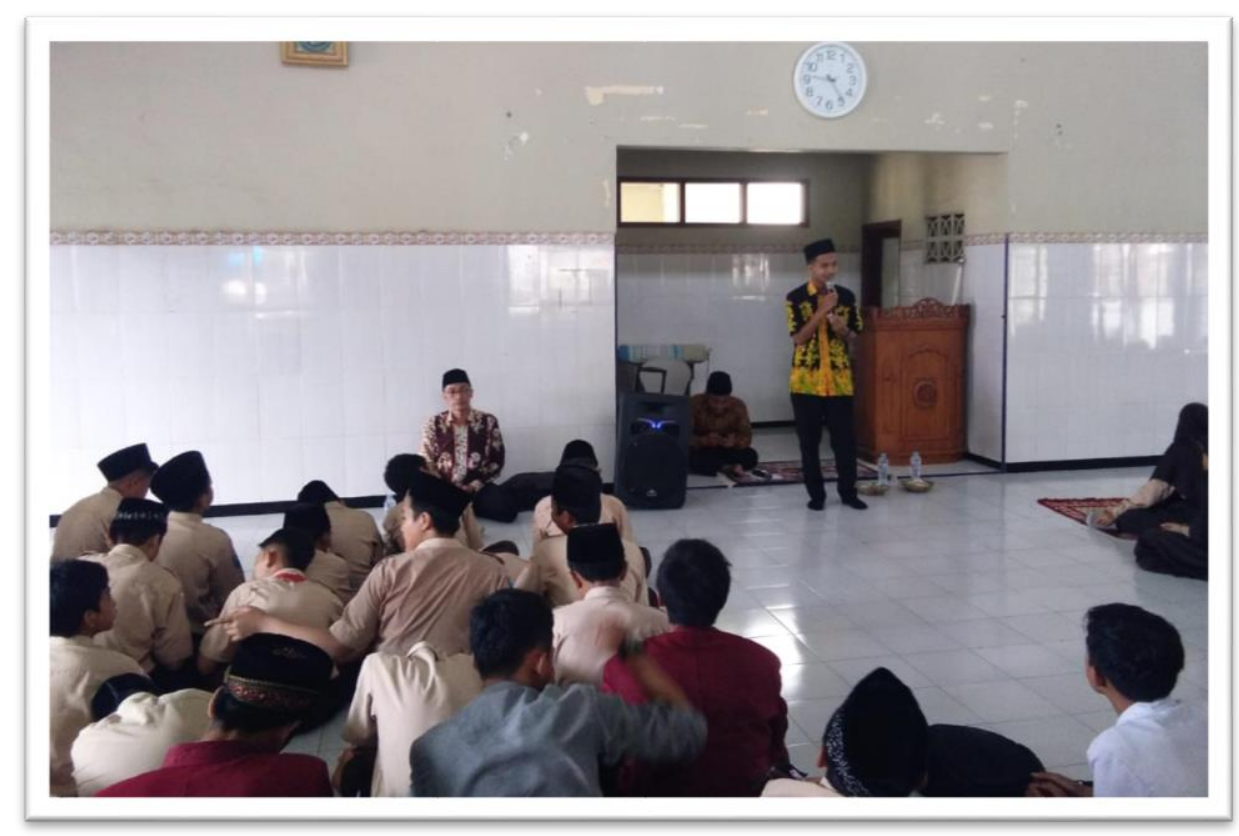

Gambar 3. Sesi Tanya Jawab 
125 | Membangun Altruisme Pada Siswa SMP

Bustanul Makmur Genteng Banyuwangi

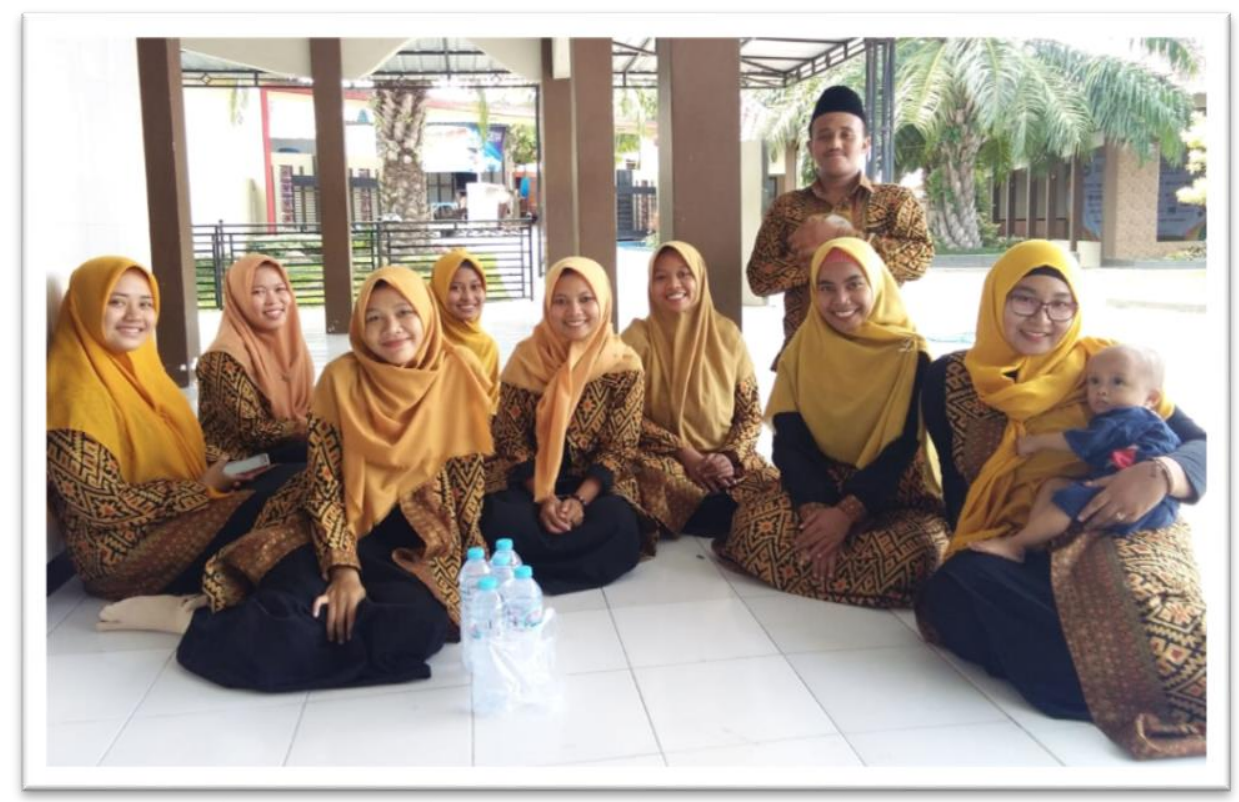

Gambar 4. Panitia Kajian Keislaman (PPL II)

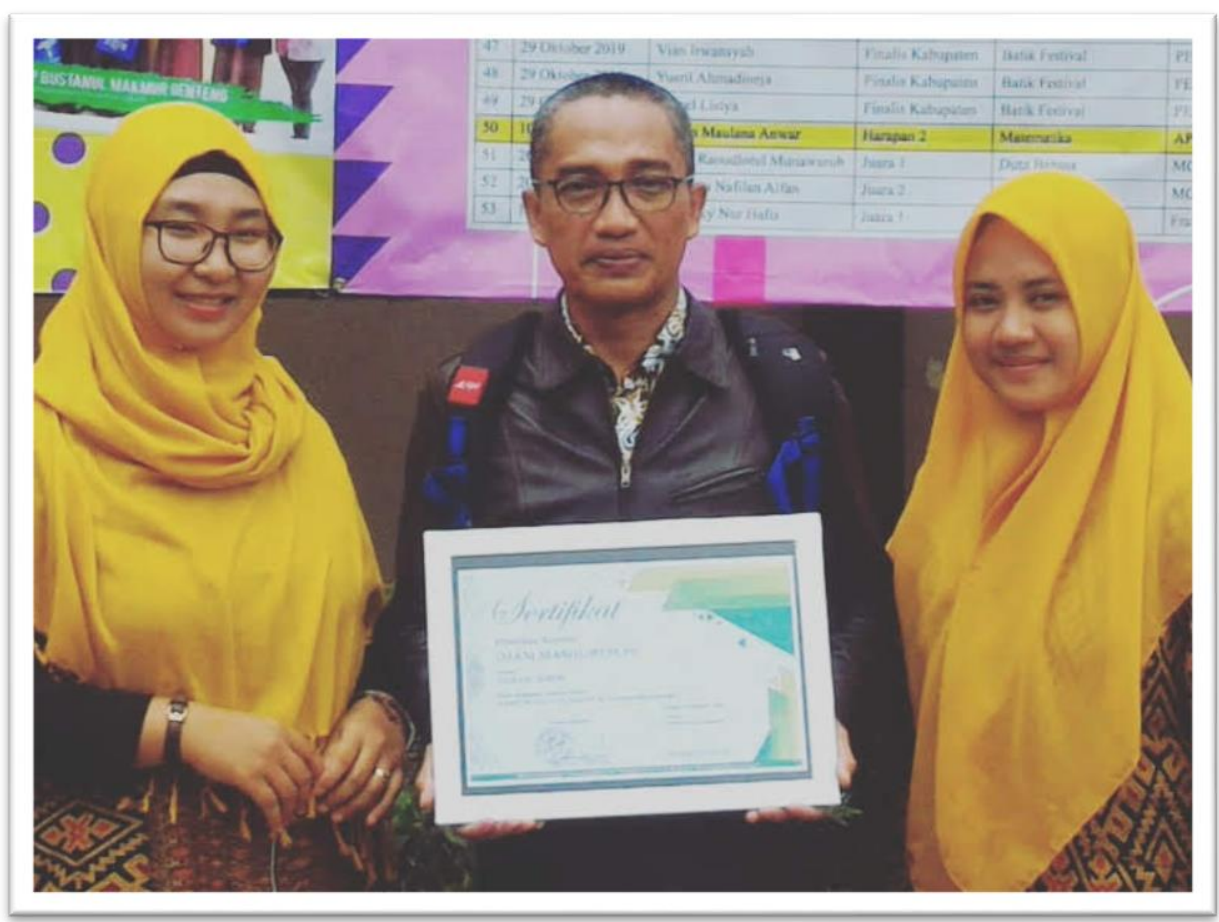

Gambar 5. Pemberian Sertifikat oleh Panitia

Jurnal ABDI KAMI (Jurnal Pengabdian Kepada Masyarakat) | Vol. 4 No. 1 (2021) LPPM IAI IBRAHIMY GENTENG BANYUWANGI 


\section{SIMPULAN}

Berdasarkan uraian di atas dapat disimpulkan bahwa membangun sikap altruisme harus dimulai sejak dini, dengan mengenalkan landasan dalil-dalil nash yang berkaitan dengan perintah untuk beraklaqul karimah serta larangan berbuat mungkar, berbuat kerusakan dan beraklakul syaiyiah. Memberikan motivasi kepada siswa dengan memberikan contoh kisah orang-orang sholeh masa lalu yang mengedepankan sikap beraklaqul karimah kepada sesama. Memberikan gambaran manfaat beraklaqul karimah dan mudharat yang disebabkan beraklaqul syaiyiah.

\section{DAFTAR RUJUKAN}

Abercrombie, Nicholas, \& et al. (2010). Kamus Sosiologi. Pustaka Pelajar.

Asy Syarifain, K. al H. (n.d.). Al Qur'an dan Terjemahnya.

Departemen Pendidikan dan Kebudayaan. (1990). Kamus Besar Bahasa Indonesia. Balai Pustaka.

Desmita. (2008). Psikologi Perkembangan. Remaja Rosdakarya.

Desmita. (2010). Psikologi Perkembangan Peserta Didik. Remaja Rosdakarya.

Faishol, R. (2018). Pengembangan Paket Pembelajaran Ilmu Pengetahuan Sosial (IPS) Kelas IV Menggunakan Model Dick, Carey \& Carey di SD Negeri 2 Tamanagung. Tarbiyatuna: Kajian Pendidikan Islam, 2(2), 31-49.

Faturochman. (2009). Pengantar Psikologi Sosial. Pustaka Pelajar.

Myers, D. G. (2012). Social Psychology (10th ed.). Mc Graw Hill.

Pillavin, J. A., \& Charng, H. W. A. (1990). A Review of Recent Theory and Research. University of Wisconsin, Madison, Winconsin.

S. Reber, A., \& Reber, E. S. (2010). Kamus Psikologi (Y. Santoso (ed.)). Pustaka Pelajar.

Sarwono. (2009). Psikologi Sosial, Individu \& Teori Psikologi Sosial. Balai Pustaka.

Sarwono, \& Eko. (2009). Psikologi Sosial. Salemba Humanika.

Sarwono, S., \& Meinarno. (1999). Psikologi Sosial. Salemba Humanika. 